LEADERSHIP, 1(2), Juni 2020, ISSN (online) : :2715-0399 I

ISSN (Print out) : 2721-7108

Homepage : http://e-journal.staima-alhikam.ac.id/index.php/mpi

DOI $\quad: 10.32478 /$ leadership.v1i2.441

Article type : Original Research Article

\title{
KEPEMIMPINAN KEPALA PONDOK PESANTREN DALAM \\ MENGIMPLEMENTASIKAN PROGRAM LINGKUNGAN BERBAHASA ARAB DI PONDOK PESANTREN DARUTTAUHID MALANG
}

\author{
Oleh: \\ Mochammad Faris Aresy \\ STAI Ma'had Aly Al-Hikam Malang
}

\begin{abstract}
Communicating using Arabic is an obligation that must be done by students at Daruttauhid Islamic Boarding School in Malang. In implementing this policy it is necessary to have a figure to emulate who can also guide, and direct the civitas in shaping the Arabic language environment so that all process activities are carried out properly and smoothly. The purpose of this study is to describe the leadership and efforts of the head of Islamic boarding school in implementing the Arabic language environment program along with its supporting and inhibiting factors. This research uses descriptive qualitative research methods, with the type of case study research, where the research location is Daruttauhid Islamic Boarding School Malang. The data is obtained directly from the head of the hut and other competent parties in the hut. The process of collecting data uses interview observation and documentation techniques which are analyzed descriptively through the editing process with the stages of data reduction, data presentation, and drawing conclusions. From the results of this study indicate that (1) The leadership of Islamic boarding school heads in Daruttauhid Islamic Boarding School in Malang in implementing Arabic language programs using the type of authoritarian leadership that can be seen in the programs and regulations of Islamic boarding schools that run in an orderly and conducive manner and and sometimes with democratic leadership it can be seen with the monthly meetings and harmonious relations between

Email Addres: mfarisaresy@gmail.com
\end{abstract}

LEADERSHIP: Jurnal Mahasiswa Manajemen Pendidikan is licensed under The CC BY License (https://creativecommons.org/licenses/by-sa/4.0/ ) 
LEADERSHIP, 1(2), Juni 2020, ISSN (online) : 2715-0399 I

ISSN (Print out) : 2721-7108

Homepage : http://e-journal.staima-alhikam.ac.id/index.php/mpi

DOI $\quad: 10.32478 /$ leadership.v1i2.441

Article type : Original Research Article

the head of the hut with the religious teachers and students. (2)

The efforts of the head of the boarding school at the Daruttauhid in developing an Arabic language environment program include forming a santri organization namely language section, holding Arabic conversation, provisioning Arabic vocabulary, additional lessons for basic class, Arabic speech training, watching films in Arabic. (3) Supporting factors that can launch this Arabiclanguage environmental activity are the religious teachers here are the majority of Middle Eastern graduate. The inhibiting factors are facing new students who cannot speak Arabic and students who are ashamed to express their words, the mixing of Indonesian or Javanese with Arabic.

Keywords: Leadership of Head Master, Arabic Language Environment

Abstraks: Berkomunikasi menggunakan bahasa Arab adalah kewajiban yang harus dilakukan oleh siswa di Pondok Pesantren Daruttauhid di Malang. Dalam menerapkan kebijakan ini, perlu memiliki sosok untuk ditiru yang juga dapat membimbing, dan mengarahkan masyarakat dalam membentuk lingkungan bahasa Arab sehingga semua kegiatan proses dilakukan dengan baik dan lancar. Tujuan dari penelitian ini adalah untuk mendeskripsikan kepemimpinan dan upaya kepala pesantren dalam menerapkan program lingkungan bahasa Arab beserta faktor pendukung dan penghambatnya. Penelitian ini menggunakan metode penelitian kualitatif deskriptif, dengan jenis penelitian studi kasus, dimana lokasi penelitiannya adalah Pondok Pesantren Daruttauhid Malang. Data diperoleh langsung dari kepala pondok dan pihak lain yang kompeten di pondok. Proses pengumpulan data menggunakan teknik observasi wawancara dan dokumentasi yang dianalisis secara deskriptif melalui proses editing dengan tahapan reduksi data, penyajian data, dan penarikan kesimpulan. Dari hasil penelitian ini menunjukkan bahwa (1) Kepemimpinan kepala pondok pesantren di Pondok Pesantren Daruttauhid di Malang dalam menerapkan program bahasa Arab menggunakan jenis kepemimpinan otoriter yang dapat dilihat 
LEADERSHIP, 1(2), Juni 2020, ISSN (online) : 2715-0399 I

ISSN (Print out) : 2721-7108

Homepage : http://e-journal.staima-alhikam.ac.id/index.php/mpi

DOI $\quad: 10.32478 /$ leadership.v1i2.441

Article type : Original Research Article dalam program dan peraturan pondok pesantren yang berjalan dengan tertib dan kondusif dan dan kadang-kadang dengan kepemimpinan yang demokratis dapat dilihat dengan pertemuan bulanan dan hubungan yang harmonis antara kepala pondok dengan para guru agama dan siswa. (2) Upaya kepala sekolah asrama di Daruttauhid dalam mengembangkan program lingkungan bahasa Arab termasuk membentuk organisasi santri yaitu bagian bahasa, mengadakan percakapan bahasa Arab, menyediakan kosa kata Arab, pelajaran tambahan untuk kelas dasar, pelatihan pidato bahasa Arab, menonton film dalam bahasa Arab. (3) Faktor pendukung yang dapat meluncurkan kegiatan lingkungan berbahasa Arab ini adalah para guru agama di sini adalah mayoritas lulusan Timur Tengah. Faktor penghambatnya adalah siswa baru yang tidak bisa berbicara bahasa Arab dan siswa yang malu mengekspresikan kata-kata mereka, campuran bahasa Indonesia atau bahasa Jawa dengan bahasa Arab.

Kata kunci: Kepemimpinan Kepala Sekolah, Lingkungan Bahasa Arab

\section{A. PENDAHULUAN}

Bahasa Arab adalah bahasa yang digunakan sebagai bahasa sains dan komunikasi. Selain menjadi bahasa internasional, bahasa Arab adalah salah satu bahasa resmi Perserikatan Bangsa-Bangsa. ${ }^{1}$ Bahasa Arab digunakan sebagai bahasa pertama di 22 negara Arab dan sebagai bahasa kedua di banyak negara Muslim. Ini menunjukkan bahwa sepertujuh negara di dunia menjadikan bahasa Arab sebagai bahasa utama mereka. ${ }^{2}$.

Al-Qur'an dan Hadits adalah referensi utama seluruh pendidikan Islam, baik aqidah syari'ah, akhlaq, mu'amalah, fiqih, dll. Al-Qur'an diturunkan dalam bahasa Arab, begitu juga dengan Hadits, dalam penulisannya juga menggunakan bahasa Arab, sayangnya,

\footnotetext{
${ }^{1}$ Ahmad Murtadi Anshor, Pengajaran Bahasa Arab Media dan Metode - Metodenya (Yogyakarta : Teras, 2009), hlm. 1.

${ }^{2}$ Yayan Nurbayan, Metodologi Pembelajaran Bahasa Arab (Bandung: Zein AlBayan, 2008), hlm. 16-17.

140
} 
LEADERSHIP, 1(2), Juni 2020, ISSN (online) : 2715-0399 I

ISSN (Print out) : 2721-7108

Homepage : http://e-journal.staima-alhikam.ac.id/index.php/mpi

DOI $\quad: 10.32478 /$ leadership.v1i2.441

Article type : Original Research Article

sebagian besar umat muslim tidak mengerti bahasa Arab, meskipun tulisan kitab suci mereka berbahasa Arab.

Bahasa Arab harus diajarkan pada tingkat tertentu, dalam lingkungan tertentu, pada waktu dan tempat tertentu. Belajar bahasa Arab sebagai bahasa asing membutuhkan proses yang panjang dan bertahap. Bahasa adalah serangkaian kebiasaan yang saling terkait. Suatu tindakan akan menjadi kebiasaan ketika tindakan tersebut diulang hingga beberapa kali. Dalam meningkatkan kebiasaan ini, sangat penting untuk memberikan rangsangan khusus untuk meningkatkan keterampilan bahasa menjadi lebih baik. ${ }^{3}$ Oleh karena itu, untuk mencapai hasil yang ditargetkan, banyak lembaga, seperti pesantren dan sekolah Islam, menerapkan sistem pengembangan bahasa Arab yang bermacam-macam, salah satunya adalah dengan bi'ah luhgowiyah / asramaisasi lingkungan berbahasa Arab. $^{4}$

Kepala pondok pesantren adalah seorang staf fungsional yang mengepalai, mengetuai, dan memimpin warga pondok pesantren (pendidik, tenaga pendidik, dan santri). Sehingga proses pembelajaran dan terlaksananya budaya religius yang ada di pondok pesantren termasuk program lingkungan berbahasa arab dapat berjalan dengan baik dan lancar.

Dengan demikian kepala pesantren memiliki tanggung jawab yang sangat tinggi untuk kelangsungan dan pengembangan kegiatan dan proses pembelajaran secara keseluruhan di pesantren, dan bahkan dapat dikatakan kemajuan pesantren ditentukan oleh kepala pesantren.

Melihat pada pentingnya menciptakan lingkungan berbahasa Arab Pondok Pesantren Daruttauhid Malang mengusahakan dengan sungguh-sungguh agar para santri tidak hanya mahir dalam mengartikan kitab kuning, menulis kalimat bahasa arab saja akan tetapi para santri sejak pertama kali didirikan Pondok Pesantren

\footnotetext{
${ }^{3}$ Muljanto Sumardi, Pengajaran Bahasa Asing Sebuah Tinjauan dari Metodologi (Jakarta: Bulan Bintang, t.th), hlm. 56.

${ }^{4}$ Jailani Musni, Psikolinguistik Pembelajaran Bahasa Arab (Bandung: Humoniora, 2009), hlm. 22.
} 
LEADERSHIP, 1(2), Juni 2020, ISSN (online) : 2715-0399 I

ISSN (Print out) : 2721-7108

Homepage : http://e-journal.staima-alhikam.ac.id/index.php/mpi

DOI $\quad: 10.32478 /$ leadership.v1i2.441

Article type : Original Research Article

Daruttauhid hingga sekarang diwajibkan memakai bahasa Arab apabila berkomunikasi sesama temannya.

Berangkat dari permasalahan di atas, sehingga peneliti tergerak untuk meneliti kepemimpinan kepala pondok dalam mengimplementasikan program lingkungan berbahasa Arab. Harapannya yakni dapat dijadikan bahan kajian tentang program pembentukan lingkungan bahasa Arab, serta hal-hal terkait yang dibutuhkan dalam mencapai tujuan dari program lingkungan bahasa Arab melalui kebijakan, strategi dan evaluasi yang dilakukan oleh kepala pondok pesantren.

\section{B. METODE PENELITIAN}

Penelitian ini menggunakan pendekatan kualitatif dan jenis penelitian ini adalah studi kasus dengan cara mengupas secara mendalam bagaimana kepemimpinan kepala pondok pesantren dalam mengimplementasikan program lingkungan bahasa Arab di Pondok Pesantren Daruttauhid Malang. Dalam penelitian kualitatif peneliti merupakan instrument kunci (The Key Instrument). Hal ini sesuai dengan Guba dan Lincoln dalam Lexy Moleong yang mengemukakan bahwa "Peneliti adalah segalanya dari keseluruhan penelitian". ${ }^{5}$

Dalam penelitian ini subyek penelitiannya adalah kepala pondok pesantren di Pondok Pesantren Daruttauhid Malang sebagai informan utama, dan juga ustadz, pengurus inti dan santri di Pondok Pesantren Daruttauhid Malang sebagai informan tambahan.

teknik pengumpulan data yang peneliti gunakan dalam penelitian ini adalah dengan tiga metode, yaitu: wawancara, observasi, dan dokumentasi. Dan dalam menganalisis data menggunakan teknik reduksi data, penyajian data verifikasi atau menarik kesimpulan. Untuk mengetahui keabsahan data yang didapat selama penelitian berlangsung di Pondok Pesantren Daruttauhid Malang maka peneliti menggunakan beberapa teknik

\footnotetext{
${ }^{5}$ Lexy J. Moleong, Metodologi Penelitian Kualitatif Bandung: Remaja, Remaja Rosdakarya, 2006), hlm. 121.
} 
LEADERSHIP, 1(2), Juni 2020, ISSN (online) : 2715-0399 I

ISSN (Print out) : 2721-7108

Homepage : http://e-journal.staima-alhikam.ac.id/index.php/mpi

DOI $\quad: 10.32478 /$ leadership.v1i2.441

Article type : Original Research Article

yaitu : triangulasi, perpanjangan keikutsertaan, ketekunan pengamatan, pengecekan teman sejawat

\section{LITERATURE REVIEW}

\section{Kepimimpinan Kepala Pondok}

Secara teori, para ilmuwan berbeda dalam interpretasi kepemimpinan, setidaknya salah satu definisi di bawah ini adalah untuk mewakili atau menjawab makna kata "kepemimpinan", sebagaimana dinyatakan oleh para ahli sebagai berikut:

a. Menurut Robin seperti dikutip oleh Sudarwan Danim dan Suparno, kepemimpinan adalah kemampuan untuk mempengaruhi kelompok dalam mencapai tujuan. ${ }^{6}$

b. J. Salusu dalam Abd. Wahab dan Umiarso mendefinisikan kepemimpinan sebagai kekuatan untuk mempengaruhi orang lain untuk berpartisipasi dalam pencapaian tujuan bersama.

c. George R Terry mengatakan dalam bukunya "Prinsip Manajemen" kepemimpinan didefinisikan sebagai kemampuan untuk mengarahkan pengikutnya untuk bekerja dengan percaya diri dan secara akurat melakukan tugas-tugas yang diberikan oleh para pemimpin mereka.. ${ }^{7}$

Dari teori kepemimpinan yang diajukan oleh para ahli yang disebutkan di atas, dapat ditarik kesimpulan bahwasanya konsep kepemimpinan adalah proses mempengaruhi seseorang atau kelompok untuk mencapai tujuan organisasi. "Proses" berarti terjadinya serangkaian tindakan, prosedur, atau proses yang menciptakan suatu produk. Dengan cara ini, proses mempengaruhi, kepemimpinan oleh kepala pondok terhadap bawahan atau santri, tidak berhenti sampai tujuan yang ditetapkan menjadi kenyataan. Produk yang dimaksud adalah tujuan organisasi.

\footnotetext{
${ }^{6}$ Baharuddin \& Umiarso, Kepemimpinan Pendidikan Islam (Jokjakarta : Ar-Ruzz Media, 2012), hlm. 47.

${ }^{7}$ George R Terry, Prinsip-Prinsip Manajemen (Jakarta: Bumi Aksara, 2009), hlm. 152.
} 
LEADERSHIP, 1(2), Juni 2020, ISSN (online) : 2715-0399 I

ISSN (Print out) : 2721-7108

Homepage : http://e-journal.staima-alhikam.ac.id/index.php/mpi

DOI $\quad: 10.32478 /$ leadership.v1i2.441

Article type : Original Research Article

Oleh karena itu, kepemimpinan secara umum dan dari perspektif Islam tidak lalim dan tanpa koordinasi. Pemimpin yang baik selalu didasarkan pada prinsip-prinsip kepemimpinan, termasuk selalu memberikan prioritas pada musyawarah secara obyektif dan penuh hormat, membuat keputusan yang lebih adil, memberikan kebebasan berpikir, dan meminta pendapat kepada bawahan untuk menciptakan demokrasi.

\section{Lingkungan Bahasa Arab}

a. Pengertian Lingkungan

Para ilmuwan telah mendefinisikan lingkungan sebagai berikut:

1) Marzuki mengatakan bahwa lingkungan adalah segala sesuatu dan faktor fisik yang membuat santri tertarik dan mendorong mereka untuk menggunakannya dan menerapkannya dalam keseharian hidup mereka.

2) Muhammad Majal mengatakan bahwa lingkungan adalah semua pengaruh, potensi dan kekuatan individu.

Definisi yang disebutkan di atas berbeda beda dalam pengertian mereka tetapi salah satu tujuannya adalah bahwa lingkungan adalah semua sumber daya, potensi dan kekuatan individu, yang dapat mempengaruhi upaya mereka untuk mencapai stabilitas psikologis dan fisik.

Lingkungan yang dimaksud oleh peneliti di sini adalah faktor fisik yang mempengaruhi proses pendidikan dan mendorong santri untuk meningkatkan bahasa Arab terutama maharotul kalam (keterampilan berbicara), dan menarik minat mereka untuk menerapkannya dalam keseharian hidup mereka.

b. Pengertian Bahasa dan Karakteristiknya

Bahasa dalam definisi linguistik adalah dasar dari makna aslinya dan secara istilah, Menurut para ahli bahasa memiliki beberapa pengertian sebagai berikut : 
LEADERSHIP, 1(2), Juni 2020, ISSN (online) : 2715-0399 I

ISSN (Print out) : 2721-7108

Homepage : http://e-journal.staima-alhikam.ac.id/index.php/mpi

DOI $\quad: 10.32478 /$ leadership.v1i2.441

Article type : Original Research Article

1) Amud Sulaiman Ya'qub bahasa adalah simbol lisan dan tulisan yang biasa digunakan untuk berkomunikasi sesama manusia.

2) Santoso berkata: Bahasa adalah serangkaian bunyi yang diperoleh dari kata-kata orang-orang sadar.

3) Ibnu Jinny, mendefinisikan bahasa sebagai: Suara di mana semua orang mengekspresikan tujuan mereka.

4) Mustapha al-Ghaliyyim: Kata-kata yang diungkapkan oleh semua orang untuk tujuan mereka. ${ }^{8}$

Dari definisi-definisi diatas dapat ditarik kesimpulan bahwasanya bahasa adalah kata yang digunakan oleh manusia untuk berinteraksi sesama mereka dan mengekspresikan maksud dan tujuannya.

Melihat dari definisi lingkungan dan bahasa diatas dapat dipahami bahwasanya pengertian lingkungan bahasa Arab adalah segala faktor disekitar yang mempengaruhi para santri untuk membiasakan dan menggiatkan mereka untuk berinteraksi dengan teman-teman di sekililingnya menggunakan bahasa Arab.

\section{Prasyarat Penciptaan Lingkungan Bahasa Arab}

Menciptakan lingkungan berbahasa Arab tidaklah mudah. Ada berbagai syarat yang harus dipenuhi untuk menciptakan lingkungan bahasa tersebut, yaitu:

a. Sikap positif dan apresiasi bahasa Arab dari orang-orang dekat seperti komunitas akademik lembaga, dari siswa hingga rekan kerja. Sikap dan apresiasi positif memiliki dampak besar pada pengembangan dan peningkatan keterampilan bahasa.

b. Pedoman yang jelas tentang format dan model pengembangan lingkungan bahasa Arab yang dibutuhkan

\footnotetext{
${ }^{8}$ Kusno Budi Santoso, Problematika Bahasa Indonesia, (Bandung: Angkasa, 1990), hlm. 1 .
} 
LEADERSHIP, 1(2), Juni 2020, ISSN (online) : 2715-0399 I

ISSN (Print out) : 2721-7108

Homepage : http://e-journal.staima-alhikam.ac.id/index.php/mpi

DOI $\quad: 10.32478 /$ leadership.v1i2.441

Article type : Original Research Article

oleh lembaga pendidikan. Pedoman ini sangat penting karena dapat menyatukan visi.

c. Mengembangkan Lingkungan Berbahasa Arab perlu peraturan ini bertindak sebagai regulator, serta pemantau kedisplinan berbahasa Arab dan denda karena melanggar perjanjian.

d. Seseorang yang dapat berinteraksi dengan bahasa Arab aktif. Keberadaan ustadz native speaker harus dioptimalkan fungsi dan perannya dalam pembinaan dan pengembangan kemahiran bahasa Arab. Mereka adalah tim terkemuka yang membuat penciptaan lingkungan bahasa Arab menjadi dinamis.

e. Menyediakan dana yang memadai, baik untuk pengadaan fasilitas dan penyediaan infrastruktur pendukung, dan memberikan insentif bagi perusahaan yang bergerak dan tim kreatif untuk menciptakan lingkungan berbahasa Arab.. ${ }^{9}$

\section{HASIL DAN PEMBAHASAN}

Dalam penelitian mengenai kepemimpinan kepala pondok pesantren dalam proses pelaksanaan program lingkungan berbahasa Arab di Pondok Pesantren Daruttauhid Malang ini telah memberikan tentang bagaimana sikap dan kebijakan kepala pondok pesantren di Pondok Pesantren Daruttauhid Malang. Di pondok pesantren ini para santri diwajibkan untuk menggunakan bahasa Arab jika berbicara kepada ustadz ataupun kepada kawan-kawannya sejak pertama kali pondok ini didirikan oleh Ustadz Abdullah bin Awad Abdun.

Adapun sanksi jika ada santri yang tidak berbahasa Arab maka hukumannya bermacam-macam, tergantung tingkat kelasnya jika masih kelas tamhidi maka masih diberi keringanan sampai 3 bulan karena santri tersebut masih belum banyak menguasai kosakata bahasa Arab maka para ustadz dan santri lainnya wajib untuk mengajarinya dengan membalasnya dengan percakapan bahasa Arab lalu diterjemahkan dengan bahasa Indonesia. Adapun di

\footnotetext{
${ }^{9}$ Syaiful Mustofa, Strategi Pembelajaran Bahasa Arab Inovatif (Malang: UIN Maliki Press, 2011), hlm. 138-139. 
LEADERSHIP, 1(2), Juni 2020, ISSN (online) : 2715-0399 I

ISSN (Print out) : 2721-7108

Homepage : http://e-journal.staima-alhikam.ac.id/index.php/mpi

DOI $\quad: 10.32478 /$ leadership.v1i2.441

Article type : Original Research Article

kelas ibtida'i sampai tsanawi maka para santri yang tidak berbahasa Arab akan diberi hukuman sesuai yang peneliti amati di pamflet tata tertib santri bahwa berbahasa Arab atau bagi santri tingkat Ibtidaiyah dan Tsanawiyah adalah wajib dan di pamflet itu juga tertera jenis pelangggaran dan sanksi yang akan diterima. Adapun hukumanhukumannya antara lain dengan menulis kosakata bahasa Arab di papan tulis atau di gundul atau di denda.

Di pondok pesantren ini setiap akhir bulan selalu mengadakan rapat termasuk dalam mengevaluasi pelaksanaan program lingkungan bahasa Arab ini sesuai hasil observasi oleh peneliti kegiatan rapat ini sudah tertera dalam kalender pendidikan Pondok Pesantren Daruttauhid Malang Semester Ganjil. Dalam pengambilan keputusan kepala pondok pesantren pesantren Daruttauhid Malang mengadakan rapat yang dihadiri oleh pengasuh pondok yang nanti sebagai pengesah dari kebijakan-kebijakan yang ada beliau menerima permasalahan permasalahan lapangan yang dihadapi oleh para ustadz dan beliau juga tidak segan untuk meminta saran kepada para ustadz yang mana hasil keputusan akhir bisa menjadi kebijakan yang disepakati dan disahkan oleh pengasuh sesuai pernyataan beliau:

"Semua kebijakan di Pondok Pesantren Daruttauhid ini berdasarkan rapat bersama para ustadz setiap bulannya. Jadi segala kebijakan di pondok pesantren ini berdasarkan evaluasi dari problematika yang dihadapi oleh para ustadz di lapangan yang mana hasil keputusannya nanti disahkan oleh pengasuh yaitu Ustadz Husein bin Abdullah Abdun.." ${ }^{10}$

Kepala Pondok Pesantren Daruttauhid ini sebagaimana peneliti amati beliau telah melakukan keteladanan kepada seluruh civitas pondok pesantren beliau memaksa para ustadz untuk menggunakan bahasa Arab walaupun statusnya sudah tidak menetap di pondok pesantren akan tetapi beliau tetap mewajibkan para ustadz untuk berkomunikasi memakai bahasa Arab sesama ustadz selagi berada di kawasan pondok pesantren. bahkan kepada tamu yang ia adalah alumni pondok saat beliau temui dalam satu ruangan

${ }^{10}$ Taufiq Hidayat, Wawancara (Malang, 30 Juli 2019). 
LEADERSHIP, 1(2), Juni 2020, ISSN (online) : 2715-0399 I

ISSN (Print out) : 2721-7108

Homepage : http://e-journal.staima-alhikam.ac.id/index.php/mpi

DOI $\quad: 10.32478 /$ leadership.v1i2.441

Article type : Original Research Article

bersama peneliti ketika ingin mengizinkan anaknya izin pulang berobat beliau selalu menggunakan bahasa Arab dan hanya sekali kali beliau menggunakan bahasa Indonesia,sehingga tidak heran kalau beliau pernah mendapatkan piagam penghargaan guru teladan oleh pengasuh langsung yaitu Ustadz Husein bin Abdulloh Abdun.

Upaya kepala pondok pesantren dalam menciptakan lingkungan berbahasa Arab secara kondusif di pesantren ini ada berbagai macam berdasarkan yang peneliti dapat dari hasil wawancara kepada kepala pondok pesantren yaitu sebagai berikut:

"Pertama, upaya yang kita lakukan adalah membentuk qismullughoh(bagian bahasa),organisasi santri ini semacam OSIS yang dipilih dari santri senior untuk mencatat adik-adik kelas mereka atau teman sebayanya yang tidak berbicara bahasa Arab, setiap tahun akan ada perubahan struktur organisasi dari qismullughoh ini dan akan dikader penggantinya santri senior yang memiliki kemampuan bahasa Arab aktif dan mampu untuk mengajak temannya aktif dalam berbahasa Arab. Selanjutnya dengan mengadakan Muhadatsah (Percakapan Bahasa Arab),kegiatan muhadatsah ini setiap minggu dilakukan 1 kali oleh qismul lughoh dengan memilih salah satu santri agar mereka bercakap-cakap dengan salah satu qismul lughohsecara langsung tanpa persiapan sebelumnya dengan pertanyaan-pertanyaan sehari-hari dalam bahasa Arab. Tempat untuk melakukan kegiatan ini yaitu di Masjid Mubarok,kegiatan ini dilakukan setelah sholat Isya'.Ada juga kegiatan Tazwidul Mufrodat(Pembekalan Kosakata), kegiatan ini adalah menulis kosakata atau percakapan bahasa Arab di papan tulis oleh qismul lughoh yang mana papan tulis ini setiap hari setelah salat magrib diperbarui dengan kosakata dan percakapan bahasa Arab yang baru yang mana kosakata dan percakapan bahasa Arab tersebut sering dipakai dalam kegiatan sehari-hari.Biasanya dalam satu hari qismul lughoh menulis 60 kosakata bahasa Arab dan paling banyak sehari menulis 100 kosakata bahasa Arab dan papan tulis ini sudah tersebar dari penjuru asrama santri dan ada juga yang di masjid. Selanjutnya I'lanatul Arobiyah, kegiatan ini adalah 
LEADERSHIP, 1(2), Juni 2020, ISSN (online) : 2715-0399 I

ISSN (Print out) : 2721-7108

Homepage : http://e-journal.staima-alhikam.ac.id/index.php/mpi

DOI $\quad: 10.32478 /$ leadership.v1i2.441

Article type : Original Research Article

menggumumkan dengan bahasa Arab suatu pengumuman dengan microphone semisal memanggil santri yang tidak berbahasa Arab untuk menghadap ustadz atau mengumumkan jika ada acara yang dibuat oleh pengasuh untuk berkumpul di masjid atau bisa juga untuk memanggil santri yang menerima paketan atau menerima telepon dari orang tuanya." ${ }^{11}$

Faktor pendukung yang dapat melancarkan kegiatan lingkungan berbahasa Arab ini yaitu kegiatan lingkungan bahasa Arab diawasi langsung oleh pengasuh pondok pesantren dan berada di asrama santri yang ketat, saling sinergi antara pengasuh, kepala pondok, para ustad dan santri bagian bahasa dalam menjalankan program-program lingkungan bahasa, para ustadz mayoritas lulusan pondok pesantren dan universitas dari Negara Timur Tengah. Adapun faktor penghambatnya yaitu adalah menghadapi santri baru yang tidak bisa berbicara bahasa Arab dan santri yang malu untuk mengekspresikan kata-katanya, campur aduknya bahasa Indonesia atau Jawa dengan bahasa Arab dan kurangnya santri bagian bahasa dan ustadz yang menetap di pondok.

Kepemimpinan adalah proses mempengaruhi dalam menentukan tujuan organisasi. ${ }^{12}$ Kepala pondok pesantren sebagai seorang pemimpin yang diberi wewenang oleh pengasuh pondok pesantren untuk memimpin dan mengatur kebijakan yang ada di dalam pondok pesantren yang ia pimpin dan harus bertanggung jawab atas segala persoalan di dalamnya oleh karena itu pondok pesantren akan maju atau mundur tergantung bagaimana kepemimpinan dari kepala pondok pesantren itu sendiri.

Berdasarkan hasil wawancara dan observasi yang peneliti dapatkan kepemimpinan kepala pondok pesantren dalam mengimplementasikan program lingkungan bahasa Arab diperoleh penjelasan sebagai berikut:

\footnotetext{
${ }^{11}$ Taufiq Hidayat, Wawancara (Malang, 30 Juli 2019).

${ }^{12}$ Mulyadi, Kepemimpinan Kepala Madrasah Dalam Membangun Budaya Mutu (Malang: Malang: UIN Maliki Press, 2010), hlm.1.
} 
LEADERSHIP, 1(2), Juni 2020, ISSN (online) : 2715-0399 I

ISSN (Print out) : 2721-7108

Homepage : http://e-journal.staima-alhikam.ac.id/index.php/mpi

DOI $\quad: 10.32478 /$ leadership.v1i2.441

Article type : Original Research Article

Dalam pengambilan keputusan untuk menentukan kebijakan sebagai Kepala Pondok Pesantren Daruttauhid Ustadz Drs. Taufiq Hidayat beliau adalah seorang yang sangat demokratis terlihat dari cara beliau ketika rapat beliau menerima saran dari para ustadz beliau tidak memutuskan sesuatu kecuali setelah disepakati bersama demi menghasilkan kebijakan yang tidak memberatkan kepada semua pihak. Hal ini serupa dengan yang dikatakan oleh Sofyan Syafri Harahap dalam bukunya Manajemen Kontemporer bahwa ciri-ciri kepemimpinan demokratis antara lain adalah saran dan pendapat selalu diterima bahkan kritik dari bawahan. ${ }^{13}$ Dan juga dalam situasi tertentu beliau menggunakan kepemimpinan otoriter dalam menetapkan peraturan-peraturan dan kebijakan sebagaimana terlihat bahwasannya beliau memaksa para ustadz untuk menggunakan bahasa Arab walaupun statusnya sudah tidak menetap di pondok pesantren akan tetapi beliau tetap mewajibkan para ustadz untuk berkomunikasi memakai bahasa Arab sesama ustadz selagi berada di kawasan pondok pesantren. Sebagaimana Yayat Herujito menerangkan dalam bukunya Dasar-dasar Manajemen bahwasannya ciri-ciri kepemimpinan otoriter adalah dalam kegiatannya sering menggunakan pendekatan yang mengandung unsur paksaan dan sifat hukuman. ${ }^{14}$

Berbagai upaya telah dilakukan oleh kepala pondok pesantren pesantren Daruttauhid Malang ini dengan bantuan semua pihak baik para asatid maupun santri senior dalam mengembangkan program lingkungan berbahasa Arab di pondok ini selain dengan tidak henti-hentinya menasehati dan memberi motivasi kepada para santri agar mereka mencintai bahasa Arab dan menggunakannya sebagai bahasa keseharian mereka masih banyak lagi upaya-upaya yang dilakukan oleh Ust. Drs. Taufiq Hidayat antara lain yaitu:

1. Membentuk organisasi santri yang bernama qismullughoh, yang mana mereka bertugas untuk memantau dan mengawasi

\footnotetext{
${ }^{13}$ Sofyan Syafri Harahap, Manajemen Kontemporer (Jakarta: PT.Raja Grafindo, 1996), hlm. 36.

${ }^{14}$ Yayat Herujito, Dasar-dasar Manajemen (Jakarta: Grasindo, 2001), hlm. 185. 150
} 
LEADERSHIP, 1(2), Juni 2020, ISSN (online) : 2715-0399 I

ISSN (Print out) : 2721-7108

Homepage : http://e-journal.staima-alhikam.ac.id/index.php/mpi

DOI $\quad: 10.32478 /$ leadership.v1i2.441

Article type : Original Research Article

kedisiplinan kawan-kawan mereka dalam keaktifan berbicara menggunakan bahasa Arab.

2. Mengadakan kegiatan Muhadatsah (Percakapan Bahasa Arab), kegiatan muhadatsah ini diadakan setiap minggu sekali oleh Ustadz pembina qismullughoh dengan memilih salah satu santri agar mereka bercakap-cakap dengan salah satu qismullughoh secara langsung tanpa persiapan sebelumnya dengan pertanyaan-pertanyaan sehari-hari dalam bahasa Arab.

3. Tazwidul mufrodat(Pembekalan Kosakata), kegiatan ini adalah menulis kosakata atau percakapan bahasa Arab di papan tulis oleh qismul lughoh yang mana papan tulis ini setiap hari setelah salat magrib diperbarui dengan kosakata dan percakapan bahasa Arab yang baru yang mana kosakata dan percakapan bahasa Arab tersebut sering dipakai dalam kegiatan sehari-hari.

4. Tamrinul Khitobah (latihan berpidato), kegiatan ini adalah belajar berpidato dalam bahasa Arab yang dilakukan setiap minggu sekali di hari Jumat setelah shalat ashar dan bertempat di Masjid Mubarok.

5. Menonton film-film yang berbahasa Arab. Kegiatan ini diadakan setiap hari kamis malam Jum'at setelah shalat Isya'

6. Rihlah Ilmiah atau studi banding, dalam rangka peningkatan dan pengembangan lingkungan bahasa Arab para ustadz dan sebagian santri melakukan studi banding di Pondok Pesantren Mamba'us Sholihin Suci Kota Gresik, karena di pondok Mamba'us Sholihin tersebut para santri juga diwajibkan menggunakan bahasa Arab dalam bahasa mereka sehari-hari.

Faktor-faktor pendukung yang dapat melancarkan kegiatan lingkungan berbahasa Arab ini yaitu para ustadz disini adalah mayoritas Alumni Timur Tengah baik Yaman Saudi ataupun Mesir. Faktor pendukung lain adalah kegiatan lingkungan bahasa Arab di pondok pesantren ini diawasi langsung oleh salah satu putra pendiri pondok pesantren Daruttauhid ini yaitu Ustadz Sholeh bin Abdullah Abdun sehingga Santri patuh dan taat dalam melaksanakan kewajiban santri untuk berkomunikasi menggunakan bahasa Arab. Adapun faktor penghambatnya yaitu adalah santri baru yang tidak 
LEADERSHIP, 1(2), Juni 2020, ISSN (online) : 2715-0399 I

ISSN (Print out) : 2721-7108

Homepage : http://e-journal.staima-alhikam.ac.id/index.php/mpi

DOI $\quad: 10.32478 /$ leadership.v1i2.441

Article type : Original Research Article

bisa berbicara bahasa Arab dan malu untuk mengekspresikan katakatanya dan kurangnya ustadz yang muqim dan santri bagian bahasa.

\section{E. KESIMPULAN}

Temuan hasil penelitian berdasarkan wawancara dan observasi terkait kepemimpinan kepala pondok pesantren dalam mengimplementasikan program lingkungan berbahasa Arab dapat disimpulkan sebagai berikut:

1. Kepemimpinan kepala pondok pesantren di Pondok Pesantren Daruttauhid Malang dalam menerapkan program lingkungan berbahasa Arab menggunakan tipe kepemimpinan otoriter hal itu terlihat pada program-program dan peraturan-peraturan pondok pesantren yang berjalan dengan tertib dan kondusif dan dan terkadang dengan kepemimpinan demokratis hal itu dapat dilihat dengan adanya rapat bulanan dan hubungan harmonis antara kepala pondok pesantren bersama para ustadz dan santri.

2. Banyak upaya yang dilakukan oleh kepala kepala pondok pesantren Daruttauhid Malang ini dalam mengembangkan program lingkungan berbahasa Arab antara lain membentuk organisasi Santri yaitu qismullughoh, mengadakan kegiatan muhadasah, tazwidul mufrodat pelajaran idhofy (tambahan) untuk tingkatan tamhidy, tamrinul khitobah, menonton film-film yang berbahasa Arab

3. Faktor pendukung yang dapat melancarkan kegiatan lingkungan berbahasa Arab ini yaitu kegiatan lingkungan bahasa Arab diawasi langsung oleh pengasuh pondok pesantren dan berada di asrama santri yang ketat, saling sinergi antara pengasuh, kepala pondok, para ustad dan santri bagian bahasa dalam menjalankan program-program lingkungan bahasa, para ustadz mayoritas lulusan pondok pesantren dan universitas dari Negara Timur Tengah. Adapun faktor penghambatnya yaitu adalah menghadapi santri baru yang tidak bisa berbicara bahasa Arab dan santri yang malu untuk mengekspresikan kata-katanya, campur aduknya bahasa Indonesia atau Jawa dengan bahasa Arab dan kurangnya santri bagian bahasa dan ustadz yang menetap di pondok. 
LEADERSHIP, 1(2), Juni 2020, ISSN (online) : 2715-0399 I

ISSN (Print out) : 2721-7108

Homepage : http://e-journal.staima-alhikam.ac.id/index.php/mpi

DOI $\quad: 10.32478 /$ leadership.v1i2.441

Article type : Original Research Article

Dalam penelitian ini banyak menghasilkan informasi dan masukan-masukan yang positif untuk menambah khazanah keilmuan khususnya dalam bidang mata kuliah kepemimpinan, maka dari itu peneliti mencoba memberikan saran dengan harapan agar penelitian lebih lanjut lebih baik lagi dan dapat menjadikan masukan bagi pihak lembaga pendidikan Islam ini yaitu Pondok Pesantren Daruttauhid Malang untuk terus mengevaluasi dan memperbaiki kekurangan yang ada.

1. Pemberian pengawasan dan bimbingan yang lebih maksimal lagi dari berbagai pihak baik kepala pondok pesantren para ustad dan santri senior yang bertugas terutama pada santri baru.

2. Selalu memberi motivasi kepada para santri tanpa bosan agar santri selalu semangat dan nyaman dalam berkomunikasi sesama teman menggunakan bahasa Arab.

3. Memberikan fasilitas yang memadai terutama televisi yang dibagi rata sehingga santri tidak berebut tempat dan semua merasa nyaman. 
LEADERSHIP, 1(2), Juni 2020, ISSN (online) : :2715-0399 I

ISSN (Print out) : 2721-7108

Homepage : http://e-journal.staima-alhikam.ac.id/index.php/mpi

DOI $\quad: 10.32478 /$ leadership.v1i2.441

Article type : Original Research Article

\section{DAFTAR RUJUKAN}

Ansor, Ahmad Murtadi. 2009. Pengajaran Bahasa Arab Media Dan Metode metodenya, Yogyakarta: Teras.

Baharuddin dan Umiarso. 2012. Kepemimpinan Pendidikan Islam. Yogyakarta : Ar-Ruzz Media.

Herujito, Yayat. 2001. Dasar-dasar Manajemen, Jakarta: Grasindo.

Lexy J, Moleong. 2011. Metodologi Penelitian Kualitatif. Bandung: Remaja Rosdakarya.

Mustofa, Syaiful. 2011. Strategi Pembelajaran Bahasa Arab Inovatif. Malang: UIN Maliki Press.

Nurbayan, Yayan. 2008. Metodologi Pembelajaran Bahasa Arab. Bandung: Zein Al-Bayan.

Syafri Harahap, Sofyan. 1996. Manajemen Kontemporer, Jakarta: PT.Raja Grafindo. 